\title{
THE ETHNO-CULTURAL ESSENCE OF LINGUISTIC CONSCIOUSNESS
}

\author{
Nikolay F. Alefirenko ${ }^{1}$ \\ Olga V. Dekhnich ${ }^{2}$ \\ Olga Y. Romashina ${ }^{3}$ \\ Olga I. Avdeeva ${ }^{4}$
}

\begin{abstract}
Each culture is based on a specific system of subject meanings, social stereotypes and cognition patterns. The "worldview" invariant is determined by socially developed supports (by meanings, in the first place). In its turn, there may be a worldview which is common for the whole society (for a socio-cultural community or ethnos) or an individual one typical of a specific group (a sociocultural group) within a given ethnos. In the process of ontogenesis, a child learns words in its native language, while lying behind these words is an integral image of consciousness comprising two layers. The first layer is
\end{abstract}

the existential one. It includes the biodynamic tissue of live movement and action, as well as a sensory image. The second layer is the reflexive one, which includes meaning and sense. Behind a language sign, there is an organic cell, which is part of a worldview typical of a specific culture. The systemic character of meanings reflects the system of concepts existing in a given culture, in a Universe structure (worldview) formed within this culture. It is the association component represented by figurative and metaphoric connotations that determines the semantic content of a cultural concept.

Key words: ethnic culture,

${ }^{1}$ Department of Russian Language and Literature, Faculty of Education, Hradec Králové University, Czech Republic.

2 Department of English Philology and Cross-Cultural Communication, Institute for CrossCultural Communication and International Relations, Belgorod National Research University, Russia.

${ }^{3}$ Department of English Philology and Cross-Cultural Communication, Institute for CrossCultural Communication and International Relations, Belgorod National Research University, Russia.

${ }^{4}$ Department of General Linguistics, Institute of Philology, Moscow Pedagogical State University, Russia. 
lexical meaning, connotations, world view, mentality, linguistic consciousness.

\section{Introduction.}

Postmodernism gave rise to a system of values where culture is a system of signs, and ethno-linguistic consciousness is a psychic mechanism of interpreting signs in terms of a specific linguistic culture. Language is understood by postmodernists as a system of behavioral guidance, with text reference being quite significant. It results in a correlation between the nonlinear worldview and non-linear linguistic worldview.

Consciousness and text are the main categories of Jacques Derrida's theory [1]. Post-structuralists perceive the world through the lens of consciousness, as a phenomenon of written culture, thus equaling individual identity to an aggregate of various texts which constitutes the world of culture.

We see ethnocultural consciousness as a result of reflection, perception and interpretation of the worldview in compliance with a specific system of values and meanings which outline the content of national cultures.
The specifics of each ethnic culture are determined by a structurized corpus of fundamental spiritual values, customs and traditions encoded in oral and written literature. It is idioms, paremiae, linguistic metaphors and invariable figures of speech that have some ethnocultural significance. These language structures provide a vivid representation of things (objects, facts and events) which are most important for a given ethnic culture. Ideas of culturally significant objects, events and facts recorded in concepts are connected with prototypical characteristics of various object classes. We hereby understand prototypical characteristics as properties which characterize objects belonging to a specific class. Such properties and their hierarchy are nation-specific. In other words, the same objects may be perceived and encoded by ethnolinguistic consciousness in compliance with the ideas of this object class existing in a respective ethnocultural community. However, the logic of their conceptualization remains the same.

Similar concepts may have different verbal representations in different languages. Let us compare 
several proverbs. The English proverb $A$ scabbed sheep mars the whole flock means the same as the Russian Паршивая овиа все стадо портит and the Ossetian И в хорошем огороде есть гнилые тыквы (word for word: there may be rotten pumpkins in a good field). Another example is the Out of sight of mind expression, with its Russian counterpart running as $C$ глаз долой из сердия вон, and the French one meaning hors des yeux et hors du coeur.

Nominative units having a high ethnocultural value include those which designate objects of everyday life (clothes, accessories, money, musical instruments etc.), as well as anthroponyms, toponyms, names of phenomena and objects of spiritual culture, rites and traditions. Connotative lexemes represent another type of nominative units where the lexical meaning nucleus is nation-specific. For instance, characteristics ascribed to animals vary from one country to another. In the USA, swine means an unpleasant and unkind person, while in Russia this animal is associated with untidiness; the Russian expression кошки скребут на душе (word for word, cats are scratching one's soul, which means anxiety) corresponds to the Polish one robak kogoś gryzie (word for word, a worm is biting someone).

\section{Ethnocultural consciousness as a category of metalinguistics}

As language is universally defined as a reality of thinking, we consider it to be the first incarnation of intelligence, the very feature which differs humans from the rest of the animate nature.

Let us refer to a work by Mikhail Lomonosov. The words he said long ago are still true today: "Word is the priority in the noble talent which differs humans from other animals, that is, in reason which controls our actions" [2]. Logocentrism has become a cornerstone for the anthropocentric trends in the contemporary science. Anthropocentrism has become the finishing touch in recognizing language as an invigorating source for the axiological and semantic space of culture. As the discursive and semantic roots of the sign date back to previous centuries, in the centre of the axiological and semantic space there is a sign which preserves the idea of creative and transformative power of word. According to Mikhail 
Lomonosov, the power of a word depends on how much knowledge has developed in the human community based on this word [2]. In the XIX century, these ideas were further developed in Humboldtian language theory, which is in fact a linguo-cultural one. This theory has specific interpretations in European and American language philosophy. In the first place, it concerns Wittgenstein's epistemological doctrine and the hypothesis of linguistic relativity, part of relativism, also known as the SapirWhorf hypothesis [3], [4].

Though these controversial theories may be polemic and require a critical reconsideration from the perspective of the XXI century science, one cannot overemphasize their contribution to the development of contemporary cultural linguistics. They enable us to understand that language is a deep source of sociocultural uniqueness. It brings specific ethnocultural communities to the limelight in respective historical eras and defines their leadership in the development of the homo sapiens cultural space.

We would like to refer to some famous facts which prove the inner connection between language and culture. It is hard to deny the obvious: the life of early Oriental civilizations was influenced by Mesopotamian and Ancient Egyptian linguistic cultures. The Ancient world culture was created on the basis of Ancient Greek language. The Medieval culture of West Europe was influenced by Latin. It is also evident that the nonethnical status of the Latin language was the main reason why it became a means of knowledge storage and transfer, bringing the European culture to a unification by suppressing national specifics of some peoples, only to become an extinct language later. On the contrary, the Arabian language, apart from becoming a means of science, culture and education in the East, has preserved its ethnic origin and remained a functional means of communication in the contemporary Arabian culture. In XV-XVIII centuries, Enlightened Absolutism was based on the axiological and semantic space of the French linguistic community.

The reality we live in today is a product of Anglo-Saxon linguistic environment which is trying to absorb ethnocultural identity of other nations 
while moving towards globalization. The abundance of foreign borrowings and slangy expressions in contemporary Russian, Ukrainian, Bulgarian, Czech and other linguistic communities of East and West Europe is a vivid example of this trend. There is no need to worry, as natural language is prone to selfpurification. However, respect of national linguistic cultures could make it possible to decrease the negative attitudes towards the linguistic situation.

Philosophers of the past realized that natural existence of each authentic culture required a non-stop invention of new forms of selfexpression based on their native culture. These included new forms in architecture, painting, music, and above all, in native language. In terms of contemporary science, they may be defined as new cultural concepts. According to A.S. Khomyakov, forms borrowed from the outside cannot express native culture, "any spiritual identity of a people may only be expressed with the forms created by this identity" [5]. That is where the problem lies. Once the word sources have become forgotten, they cannot replenish ethnic culture the way they used to,
289

causing this culture to lose its creative energy. Nikolay Trubetskoy identified culture as a historically ever-changing product collectively created by past and present generations [6]. That is why a normal development of any culture requires a storage of cultural values, the cultural inventory, which should be conveyed to the next generations by means of traditions.

Traditions are associated with the idea of a culture nucleus (an ethnic constant) referring to the unconscious collective. The culture nucleus defines the limit of admissible changes, while exceeding this limit results in a destruction of culture. According to S. Lurie, the system of ethnic constants adopted by an individual is the lens through which he or she looks at the world [7]. A child's socialization thus means adoption of an ethnic constants system which determines the specifics of our consciousness.

The consciousness of ethnic culture representatives cannot be studied directly. Instead, various forms of externalization enable us to understand it. Among such forms is linguistic consciousness, that is, "a culture representative's aggregate of perceptive, 
conceptual and procedural knowledge of real-world objects" [8]. An image in a consciousness which is associated with a word is another attempt to describe knowledge used by communicators in producing and perceiving verbal messages. A name (a word) is the cultural frame laid over a person's individual experience upon socialization in a specific culture. According to N. Ufimtseva, "nominating" means ascribing a specific meaning to a word, while ascribing a meaning implies understanding and including the concept into one's consciousness [9]. Most frequently it refers to mundane concepts.

Representatives of various ethnic groups perceive both spatial and temporal characteristics of objects and their meanings. Meanings contain internal connections of objective reality. Unlike personal interpretations, meanings record cultural stereotypes, invariant images of specific world fragments typical of a particular ethnos. Cultural stereotypes are acquired in the course of socialization. Therefore, culture cannot be abstracted from humans, it is always human-specific, that is, ethnic.

The perception of culture as a knowledge system connected with a particular ethnos is possible due to cultural stereotypes existing in a consciousness, that is, due to consciousness images paradigms which are understood as means of perception and accumulated as a collection of structurized contexts (patterns or frames). N. Zhinkin interprets a consciousness image as a perception image, saying that "an image is not something to be recognized, but rather a way of perception. Cassiopea image has been created in our perception and in our memory, while in the sky there are only discreet stars..." [10]. Our perception depends on our experience, education level, language and culture. In some circumstances (including those which involve various cultures representatives) the same stimuli may produce different impressions, and vice versa. There cannot be any common "language of observation" which would be based on the imprints left on the senses only. Contemporary scientific worldview does not allow for any unambiguous objective description 
anymore, as it used to be in Descartes' works. Bohr and Heisenberg believe that reality is construed with mental acts and depends on what we choose to observe and how we do it [11-13]. According to Heisenberg, "Because the physical world is relative to being known by a "knower" (the observing consciousness), then the "knower" can influence the nature of the reality which is being observed. In consequence, what is known vs what is not known becomes relatively imprecise" [14]. The scholar states that "the nature of reality, and the uncertainty principle is directly affected by the observer and the process of observing and knowing" [15].

Culture is also something which forms life purposes for an individual. Thus, we can describe culture as a system connected with an ethnos as a collective identity.

Each culture is based on a specific system of subject meanings, social stereotypes and cognition patterns. The "worldview" invariant is determined by supports (meanings, in the first place) produced by the society, and it may be common for the whole sociocultural community or ethnos, or for a specific group (a socio-cultural one) within a given ethnos. In the process of ontogenesis, a child learns words in its native language, while lying behind these words is an integral image of consciousness comprising two layers. The first layer is the existential one. It includes the bio-dynamic tissue of live movement and action, as well as a sensory image. The second layer is the reflexive one, which includes meaning and sense [16]. Behind a language sign, there is an organic cell, which is part of a worldview typical of a specific culture. The systemic character of meanings reflects the system of concepts existing in a given culture, in a Universe structure (worldview) formed within this culture.

It is possible to borrow a cultural phenomenon only on the reflexive level of consciousness (the knowledge which is realized), while the existential layer of consciousness cannot be borrowed. A consciousness image formed in such a way in the recipient culture is bound to be inadequate. It will take a long time to become part of the recipient culture, before a new existential layer is formed therein which would differ from that existing in the donor culture. Even in this case, the 
reflexive layer in unlikely to be fully copied.

\section{Ethnocultural constants of}

\section{linguistic consciousness}

According to Eugenio d'Ors, a constant as a category of philosophy is a reality or an idea which has dominated over other ones for a long time. Ideas suggested by d'Ors arouse interest among contemporary scholars. Pilar G. Saenz, for instance, refers to his definition of a historic constant described as "a living and archetypal category inserted in the fabric of history, in the contingent flow of events" [17].

It is archetype concepts that represent constants of culture. Yu. Stepanov explains concepts as "bundles of knowledge, emotional experience, associations accompanying a word", "a cluster of culture in human consciousness; something that enables culture to penetrate into an individual's mental world. On the other hand, a concept is a means allowing an ordinary person to join a culture, and in some cases even to influence it" [18]. Thus, a constant as a term moves beyond the exact sciences and acquires a broader linguo-philosophic meaning. That is why invariability and constistency, being constant-related characteristics of an archetype concept, become more and more relative. Constants of culture are anthropocentric, as they depend on the only subject and creator of culture, a human. Most frequently, this dependence is indirect. In other words, cultural concepts are not substantive, as they do not reflect objects of the Universe on their own. They have an operational character and represent people's manner of action in respect to objects. The world is not designed as a predetermined natural external reality, but rather as a reality formed in the course of human cultural development, with a human being in the centre of the Universe. As a rule, people are not aware of cultural constants. The latter serve as a means of regulating and rationalization of experience obtained from the external world.

Concepts are ascribed the ability to provide a subjective reflection of the world in a maximally generalized form, as vague and poorly structurized mental entities. How fair is this approach? Are all parts of a concept actually subjective? If not, what is the correlation between the subjective and the objective? Answers to these questions would enable us to 
differentiate concepts and notions, which are often similar. Absence or presence of a subjective element is the main criterion for such differentiation.

Yu.S. Stepanov's theory suggests that unlike notions, concepts have two distinguishing features, namely: 1) a specific level of subjectivity, and 2) a multi-layer structure. We do not only comprehend concepts, but actually live through them. They reflect people's emotions, likes and dislikes, and sometimes even clashes [18]. The theory of a multi-layer concept structure describes three main layers. The first one is the active, or the relevant one. It is just the tip of the iceberg, being evident for all people living in a respective period of time. It can be appealed to and used by mundane consciousness even. The second one is passive, or historical (a background). It includes additional concept features. This layer represents a solidification of its basic comprehensions and interpretations in various cultural epochs, according to Yu.S. Stepanov [18]. The third layer is the concept inner form, or its etymological characteristic, that is, its semantic beginning explicated externally in a verbal form.
The juxtaposition and complementarity of the layers described above bears testimony to a harmonic combination of permanent and varying components within a concept. The inner form, being a key pillar of a concept explicated verbally, ensures its stability and consistency. Verbal and cogitative mobility of a concept is based on the dynamic correlation between the semantic content of the relevant and the historical layers. It enables the historic content to be modified, with some meanings becoming relevant and others losing significance. Thus, a concept is always incomplete in this respect, as it remains open to structural changes.

These features are not typical of notions. Instead, they display stability, objectivity, concentration of the most characteristic features and separation from everything which is insignificant, particular and subjective. The notion of a Laconian (Spartan) may not be found in the concept of laconism (brevity). A "Spartan" meaning "Sparta inhabitant" is a notion, while the lifestyle of Spartans pursued by some people today may be treated as a concept. Besides, there are lexemes in contemporary Russian which originate from the notion 
of Spartan and describe people who live simply and unpretentiously “спартаниьь". The latter may be demonstrated with a context from Turgenev's "Nov" ("Virgin soil") novel: He retained his military habits, and lived like a Spartan and a monk [19].

To differentiate between a concept and a notion, we should stress that a notion content is intensional, while that of a concept is implicative.

Specialists in cultural linguistics are increasingly using the term of cultural concept, which is frequently ungrounded. How justified is its use alongside with the single-word term - "concept"?

It is clear a priori that the use of the cultural concept term is only fair when we do not consider all concepts to have a cultural marking. This suggestion has some grounds. Let us address metalanguage where a concept is an integral semantic entity. Apart from words, lexical and semantic variants and word form paradigms, this entity may be objectivized in a language with an aggregate of words, such as lexical and semantic groups or groups of synonyms and antonyms. It is universal knowledge arranged into a field. Conceptual categories are formed therein and encoded by the majority of existing languages. S.D. Katznelson describes them as "ontologic", "extralinguistic", "cognitive" or "verbal and cogitative" [20]. E.S. Kubryakova suggests a similar interpretation of a concept describing it as an operational substantive unit of memory, of mental lexicon, conceptual system and lingua mentalis [21]. This interpretation of a concept makes it similar to the ideas of "information" and "meaning".

However, this similarity does not mean the above are equal. Unlike a concept, information means all data that an individual receives from various sources, including sensory perceptive and sensorimotor ones (Luzina). In conventional linguistics, information means any data pertaining to facts and processes contained in the semantics of language and speech units. Information is identified as lexical and phraseological meanings in lexics and phrasemics, as propositional content of a sentence in syntax, and as communication-related pragmatic data obtained heuristically in a text. There is a notion of conceptual information in cognitive science, which denotes all 
comprehension products resulting from data obtained via various sensory canals. Apart from knowledge, these products also render beliefs, opinions and attitudes within a discourse. A concept, at the same time, is not just information. It is a kind of package for information which has been comprehended and structurized. In this respect, a concept is similar to meaning.

Some scholars use the term of concept as an equivalent to that of meaning. The opinion of a concept as an interpreter of meaning and a product of its hermeneutic processing is also grounded. This view of the concept and meaning correlation is supported by the world conceptualization and categorization theory. In the course of these two processes, the digested information is arranged into categories. Meanings, being minimal units of human experience, are structurized into concepts, while the latter are combined into categories, based on the meanings which they share. Meanings are always specified and modified within a concept to comply with the information received. That is why concepts are operational units of our consciousness.

In any case, a concept is a mental intermediary between language and the extra-linguistic world. At the same time, it does not always have ethno-cultural marking. If we agree with the idea that all concepts in a language are cultural, as some researchers believe, we will have to question the existence of cultural linguistics as a separate science.

The idea of a cultural concept being a multi-layer mental entity raises no doubt in the contemporary cultural linguistics [22], [18]. It comprises several different components (layers, or dimensions).

According to S. G. Vorkachyov, different cultural concept interpretations result from the discrepancies in defining the quantity and specifics of its semantic components. Lyapin considers the "discreet integrity" of a cultural concept to be formed out of an interaction between "a notion", "an image" and "an action" [22]. Apart from the notional component, Yu.S. Stepanov singles out "everything that turns a concept into a cultural fact", including its etymological origin, contemporary associations and assessments" [18]. V.I. Karasik believes that a cultural concept contains "axiological, figurative and notional 
aspects" [24]. S.G. Vorkachyov states that the notional component reflects the aggregate of features and definitions of a concept, while the figurative component records cognitive metaphors which support the concept in the relevant area of linguistic consciousness. The semantic component depends on the position of the concept name in the language system.

The multi-dimensional character of a cultural concept may be correlated with its complexity and internal segmentation, which allows semantically integral mental entities to obtain a cultural concept status by submerging into a linguistic environment. For example, an assessment expressing "indifference" turns into the "insensibility / apathy" concept after acquiring axiological connotations and figurative associations.

A study of cultural concepts would be impossible without a comparative analysis. Otherwise, it would be impossible: a) to reveal distinctive features of a concept as a linguo-cultural unit, b) to identify its linguo-cultural specifics. An example of an ethno-specific characteristic may be a feature which is basic to nomination, that is, the inner form of a name. Among the
296

manifestations of ethno-specifics may be a stereotypification of world perception patterns and behavioral responses reflected in the concept semantics. The ethno-specific character of a concept in the context of comparative linguistics enables us to consider it as a national mentality unit different from a mindset which is an aggregate of national characteristics.

The study shows that a cultural concept is a multi-level integrating heuristic category comprising three different components. Only one of these components, though, is determinant.

The constituting component in the concept semantics may be represented by a notion concealed beneath its other layers and therefore unavailable for a superficial perception. That is why it is impossible to describe the notional component of a concept in terms of classical logic, by listing substantial characteristics of the object cognized. Yu. Stepanov and V. Kolesov suggest that in this case it should be interpreted via negation [18], [25]. This component is not considered to be figurative, and it is not connected with the place of a concept name in a lexical system. 
Conclusion.

The basic component in the semantic content of a cultural concept is the associative one represented by figurative and metaphorical connotations. What differs it from a notion devoid of visualization is a figurative constituent (for example, a standard idea, gestalt, prototype, stereotype, symbol etc.). Moreover, the ethnocultural specific of a concept may be revealed by "material connotations" reflected in a limited combinability of a concept name [26]. V. Kolesov states that the figurative component of a concept may transform into a sign in the course of a concept verbalization [25].

The final component in the three layers of concept is the nominative one, being linguo-culturological proper, connected with the concept verbalization in a specific natural language and name-oriented.

A variety of single-level or multi-level means of concept implementation is a formal characteristic of a cultural concept. It is directly connected with the relevance and significance of the concept for any given linguo-cultural community, and with the axiological or any other value of the phenomenon reflected in its content [24]. Another manifestation of a cultural concept content relevance is whether it may be "lived through", as $\mathrm{Yu}$. Stepanov describes it [18], and if it may be in the focus of consciousness and intensify a person's spiritual life.

Synonymic means serving as the expression plane of cultural concepts are divided into groups and organized according to the frequency of their use and their functions. There are concepts of various cultural significance inside semantic families, for example: "happiness - bliss", "love - mercy", "justice - truth", "freedom" - "will", "honour" - "dignity" etc. In such pairs, it is usually the second component that is ethno-specifically marked.

$$
\text { Cultural concepts typology }
$$
may be based on the abstraction level of respective names. While the names of natural realia are not usually considered to be concepts, the names of substantive artefacts tend to acquire ethnocultural connotations and represent cultural concepts.

Still, culturally determined concepts, as well as culturally neutral ones, are first of all mental entities 
Periódico do Núcleo de Estudos e Pesquisas sobre Gênero e Direito

Centro de Ciências Jurídicas - Universidade Federal da Paraíba V. 8 - No 07 - Ano 2019 - Special Edition

ISSN | 2179-7137 | http://periodicos.ufpb.br/ojs2/index.php/ged/index reflecting the Humboldtian "peculiarity of the spirit".

All of the above determine the anthropocentric character of cultural concepts, namely, their being spiritoriented, subjective, social-oriented and personality-oriented depending on the representatives of a particular linguistic consciousness.

\section{References}

Derrida, J. (2001). Posicoes: Jacques Derrida. Belo Horizonte, MG: Autentica. (Trabalho original publicado em 1972)

Lomonosov M.V. (1952). Rossijskaya grammatika [Russian grammar]. Collected writings. Vol.7. Works in Philology. Moscow, 1952. 99 p.

Sapir, E. (1929) "The Status of Linguistics as Science," Language, 5; 207-214.

Whorf, B. L. (1956). Language, thought, and reality: Selected writings of Benjamin Lee Whorf. Edited by John B. Carroll. Cambridge, MA: MIT Press.

Khomyakov, A.S. (1994). Sochineniya $\mathrm{v}$ dvuh tomah [works in two volumes].
Vol.1. Raboty po istoriosofii [Philosophy works]. Moscow: Moskovskij filosofskij fond Izdatelstvo "Medium", 591p.

Troubetskoy, N.S. (1998). Izbrannye Trudy [Selected worls]. Kiev.

7. Lurie, S. V. (1997). Istoricheskaya etnologiya [Historical ethnology]. $1^{\text {st }}$ edition. Moscow: Aspekt Press, 448 p.

Tarasov, E.F. (2000). Aktualnye problemy analiza yazykovogo soznaniya [Cntemporary issues of linguistic consciousness analysis]. In: Yazykovoe soznanie i obraz mira / Ed. N.V. Ufimceva. Moscow: IYA RAN, pp. 24-32

Ufimceva N.V. (2000). Yazykovoe soznanie i obraz mira slavyan [Linguistic consousness and Slavic lifestyle]. In: Yazykovoe soznanie i obraz mira. Moscow, IYA RAN.

Zhinkin, N.I. (1982). Rech kak provodnik informatsii [Spech as a conductor of information]. [Predisl. R. G. Kotova, A. I. Novikova]. Moscow: Nauka. 
Bohr, N. (1934/1987), Atomic Theory and the Description of Nature, reprinted as The Philosophical Writings of Niels Bohr, Vol. I, Woodbridge: Ox Bow Press.

Bohr, N. (1958/1987), Essays 1932-1957 on Atomic Physics and Human Knowledge, reprinted as The Philosophical Writings of Niels Bohr, Vol. II, Woodbridge: Ox Bow Press.

Bohr, N. (1963/1987), Essays 1958-1962 on Atomic Physics and Human Knowledge, reprinted as The Philosophical Writings of Niels Bohr, Vol. III, Woodbridge: Ox Bow Press.

Heisenberg, W. (1955). The Development of the Interpretation of the Quantum Theory, in W. Pauli (ed), Niels Bohr and the Development of Physics, 35, London: Pergamon pp. 12-29.

Heisenberg, W. (1958), Physics and Philosophy: The Revolution in Modern Science, London: Goerge Allen \& Unwin.

Zinchenko, V.P. (1991). Miry soznaniya i struktura soznaniya [Worlds of consciousness and consciousness structure] // Voprosy psikhologii. Issue 2. Saenz, P. (1997). On the sublime. In: Tracy Chevalier. Taylor \& Francis, p.617.

Stepanov, Yu.S. (1997). Konstanty: Slovar russkoj kultury. Opyt issledovaniya [Constants: a dictionary of Russian culture. Research experience]. Moscow: Shkola "Yazyki russkoj kultury", 824p. pp.14, 41.

Turgenev, I.S. (2009). Virgin Soil. Translated from Russian by R.S. Townsend, $2009 . \quad$ URL: www.gutenberg.org/files/2466/2466h/2466-h.html\#link2H_4_0003

Katznelson, S.D. (2001). Kategorii yazyka i myshleniya: Iz nauchnogo naslediya [Language and thinking categories. From scientific heritage]. Ed. L. YU. Braude. Moscow: Yazyki slavyanskoj kultury.

Kubryakova, E.S. (1996). Kratkij slovar kognitivnyh terminov terminov [A brief dictionary of cognitive terms]. E.S. Kubryakova, V.Z. 
Demyankov, Yu.G. Pankrats, L.G.

Luzina; Ed. E.S. Kubryakova.

Moscow: Moscow State University,

Faculty of Philology, 1996. p.90

Lyapin S. Kh. (1997). Konceptologiya: k stanovleniyu podhoda [Concept studies: on the approach development]. In: Kontsepty. Issue I. Arhangelsk, pp.11-35 Vorkachoyv, S.G. (2003). Kulturniy kontsept I znacheniye [Cultural concept and meaning]. In: Works of Kuban State Technological University. Humanities. Vol.17, issue 2. Krasnodar: pp.268-276.

Karasik, V.I. (2004). Yazukovoy krug: lichnost, kontsepty, diskurs [Linguistic cirle: personality, concepts, discourse]. Moscow: Gnosis, 389 p.

Kolesov, V.V. (2002). Filosofiya russkogo slova [Philosophy of a Russian word]. SPb, YuNA, 448p. pp.64, 107.

Cherneyko, L.O. (2010). Linggvofilosofskiy analiz abstraktnogo imeni [Linguo-philosophical analysis of an abstract name], $2^{\text {nd }}$ edition, revised. Moscow: LIBROKOM, 272p 